Halász, Dorottya. "Propaganda Versus Genocide: The United States War Refugee Board and the Hungarian Holocaust." AHEA: E-journal of the American Hungarian Educators Association, Volume 5 (2012): http://ahea.net/e-journal/volume-5-2012

\title{
Propaganda Versus Genocide: The United States War Refugee Board and the Hungarian Holocaust
}

\section{Dorottya Halász, University of Miskolc}

\begin{abstract}
In 1944 the Second World War had been raging for more than four long years, with the death toll among soldiers and civilians alike climbing. European Jews constituted a special group of the victims, a fact that leaders of the Allied powers failed to acknowledge. In January 1944 a major revision of previous government policy was brought about in the United States with the establishment of the War Refugee Board in Washington, promising an American commitment to the rescue of European war refugees, including Jews. In March of the same year the situation for Jewish inhabitants in Hungary turned dire as German forces occupied the country. For lack of any other instantly applicable way to influence Hungarian developments, leaders of the new American War Refugee Board decided to launch a propaganda campaign to fight the Nazis and their accomplices. This paper will examine the motivations of American policy makers in focusing on political propaganda measures during the first phase of the Hungarian Holocaust (MarchJuly 1944), and it will describe the logic and workings of the campaign as a means to save Hungary's Jewry in the last full year of the Second World War.
\end{abstract}

Keywords: American World War II propaganda, Hungarian Jews, War Refugee Board, genocide, Allied culpability.

Biography: Dorottya Halász is Assistant Professor of Modern World History at the University of Miskolc, Hungary, where she teaches courses on twentieth-century world history, fascism, the Holocaust, the Cold War, and American history. She earned her Ph.D. at Texas Christian University, Fort Worth, Texas in 2000. Her main research interests include Jewish and Holocaust history and also U.S. social history, with a special emphasis on the twentieth century. She has published on subjects pertaining to American social and diplomatic history as well as Jewish studies.

The Allied response to the Jewish persecution in Europe during the Second World War has long been subject to fierce scholarly debate. While some historians argue that the United States and its military allies should have taken a more active stand in their attempt to prevent the Nazi genocide or, at least, to stop it at an early stage, others justify claims that the opponents of the Axis powers bear no responsibility for the outcome. Yet representatives of both schools of historians agree on concluding that the American efforts to counter German designs produced limited results. This paper does not purport to change this general view of U.S. involvement but drawing, in part, on hitherto unpublished archival materials from the records of the U.S. War Refugee Board, it strives to explore the logic and workings of the American propaganda campaign as applied to alleviate the plight of Hungary's Jewry. By using a close construction of the term Holocaust, it focuses on the single year of 1944 because prior to that date the United States had been mostly inattentive to the conditions of Jews in Hungary and because in January 1945 Hungarian Jewry ceased to possess persecuted status after the liberation of the ghettos in Budapest, the capital city.

In the spring of 1944, just as changes in the American refugee policy started to materialize in Washington with the establishment in January of that year of the War Refugee Board (WRB), the situation of Hungarian Jews was becoming acute. On March 19, the German occupation of Hungary ended a period of relative safety for Jews who were Hungarian citizens (those who could not prove Hungarian citizenship had been deported much earlier), sealing the fate of the country's Jewish population. Despite growing antiSemitism and the enactment of restrictive legislation, before the commencement of the Nazi rule in Hungary the damage in human lives had been relatively small compared to the number of victims in other countries, especially in what used to be Poland before the German attack on it in September 1939. During the pre-1944 period, approximately 60,000 Jews in Greater Hungary, who were either citizens or refugees from neighboring areas, lost their lives including 42,000 labor servicemen, 18,000 who perished in the mass 
Halász, Dorottya. "Propaganda Versus Genocide: The United States War Refugee Board and the Hungarian Holocaust." AHEA: E-journal of the American Hungarian Educators Association, Volume 5 (2012): http://ahea.net/e-journal/volume-5-2012

murders at Kamenets Podolsk in the western Ukraine (then under German occupation) in the summer of 1941, and another 1,000 who died in the massacres at Novi Sad, Serbia (then under Hungarian control) in January 1942 (Braham 2010, 42). In 1944, save for the Jews of the Soviet Union, Hungarian Jewry was thus the largest surviving Jewish community on the war-torn continent. Because of the relatively more humane treatment of Jews by the Budapest government, the United States had not paid much attention to Hungarian domestic politics prior to March 1944. By coincidence, two months before German troops marched into Hungary the War Refugee Board, the new American government agency intended to devise plans and coordinate efforts to stop or slow down the European genocide had come into existence, whose main task was to alleviate the refugee situation by various means, including the use of the propaganda machine.

Although the fact that the WRB was created late in the course of the Holocaust does not imply a total lack of interest on the part of the United States government in the situation of the Jews in Europe, it is still important to note that — despite the Allies' knowledge of the German decision to implement genocide - the process that resulted in the murder of millions of innocent people evolved largely unchecked by leaders of the Allied coalition (see Karsai 2001, 270-80 for information held by the Allies). The first fairly conclusive evidence proving the existence of the plan to exterminate all Jews under German control-meaning close to 4,000,000 people at the time - reached the American State Department in August 1942. Gerhart Riegner, the secretary general of the World Jewish Congress in Geneva, Switzerland, submitted this information to the British and American consulates requesting that their governments be also advised. The news was finally released to the American public in November 1942 but as favorable military developments at the Pacific and North African theaters attracted much greater attention in the U.S. press, the subject received only moderate media coverage (Druks 1977, 34-35; Mashberg 1978, 22-23; Wyman 1996, 705; see also Leff 2005 for an extensive study of the reasons behind the American government and media reaction). Although, on December 17 of the same year, the United States joined Great Britain, the Soviet Union, and other Allied nations in a declaration condemning the German policy of persecution and extermination as well as promising punishment for the perpetrators, future statements failed to single out Jews as the Nazis' primary targets. Developments at the Bermuda international conference in April 1943 are one telling example of the lack of action by the Allies. The original purpose of the meeting had been to work out the possibilities of Jewish rescue from Europe, but it accomplished nothing in pursuit of the goal, so much so that the theme of the conference was actually revised to be an examination of "the refugee problem" in general, "not ... confined to persons of any particular race or creed" (Adler and Margalith 1946, 422; Unity in Dispersion 1948, 164; Wyman 1996, 706).

The wording of the American presidential order of January 22, 1944, establishing the War Refugee Board reveals a tendency similar to the reasoning that caused the failure of the Bermuda conference less than a year earlier. Notwithstanding the fact that the new agency was designed to solve the mostly Jewish refugee problem, Executive Order 9417 failed to highlight the unique position of Jews in Nazi plans and stated only that it was "the policy of this Government to take all measures ... to rescue the victims of enemy oppression who are in imminent danger of death," without making any specific reference to the special persecution of the Jews (O'Dwyer 1945, n.p.). Although it was them who were ultimately to receive the Board's major attention and support, the word "Jew" itself was curiously missing from the text testifying to the indecisiveness of the United States government, which prevented it from taking an active and direct role in rescue matters that went beyond rhetoric and became a constant feature of American policy in relation to Jewish refugees.

When faced with the rapidly deteriorating conditions in Hungary, the War Refugee Board leadership decided that a propaganda campaign would be most effective in fighting the Nazis and their Hungarian accomplices, with a large part of the explanation why psychological warfare became the most cherished Board procedure in Hungary lying in timing. Since the establishment of the WRB just briefly preceded the Hungarian turnover, in March the new agency was largely inexperienced. It had just begun to build up its administrative structure and to devise schemes for rescue and relief, which included: the protection of refugees from persecution and death by evacuating them, by concealing them, or by arranging for their acquisition of the status of foreign citizens; the attempt to obtain better conditions for people en route to and already in concentration camps; the establishment of temporary havens of refuge for escapees; and the use of psychological approaches, including propaganda pressure (O’Dwyer 1945, 16-17). When confronting the 
Halász, Dorottya. "Propaganda Versus Genocide: The United States War Refugee Board and the Hungarian Holocaust." AHEA: E-journal of the American Hungarian Educators Association, Volume 5 (2012): http://ahea.net/e-journal/volume-5-2012

challenge of the Hungarian Holocaust, leaders of the War Refugee Board firmly — and rather naivelybelieved in the power of propaganda, especially of threats of post-war punishment, in part because this method required the least time to implement. As, since December 1941 there had been a state of war and hence no direct contact between Hungary and the United States, which was the result of Budapest's war message to Washington, ${ }^{1}$ the Board had to utilize the channels of neutral governments, the International Red Cross, the Vatican, and foreign and American private organizations in its work in Hungary. The latter category included, among others, the American Committee for Hungarian War Refugees, the HungarianAmerican Council of Democracy, The United Hungarian Jews of America, the Union of Orthodox Rabbis, the Emergency Committee to Save the Jewish People of Europe, the American Jewish Conference, the American Jewish Joint Distribution Committee, the Vaad Hahatzala Emergency Committee, the Swiss Relief Committee for the Jews in Hungary, and the World Jewish Congress. Because of the complexity of cooperation between the various governments and organizations, the Board could exercise influence only indirectly and with considerable delay, a problem it tried to overcome by relying on psychological warfare measures.

The extreme difficulties of physical rescue from Hungary were another impediment to the WRB's efforts. The policy of German authorities as well as the geographical location of the country in the heart of Axis-controlled Europe frustrated such plans. Legal emigration virtually ended with the German occupation because Adolf Eichmann, the organizer and supervisor of the Hungarian deportations, and his colleagues knowingly allowed Jews to escape in rare cases and only if they received sufficient compensation in return. At the same time, those willing to take the risk of illegal border-crossing had to pass through enemy territory once more after departing the country that was surrounded by Nazi-dominated areas. Also, since Hungary lacked access to the sea, refugees were limited to using slow and dangerous ground transportation. These difficult circumstances for Jewish escape from Hungary suggested to the WRB that psychological pressure would be the fastest and most effective weapon in protecting Jews, and this policy became dominant during the first phase of the Hungarian Holocaust between the German takeover in March and the end of large-scale deportations in July.

The first statements by the WRB critical of the Hungarian government's Jewish policy were issued almost as soon as occupying forces arrived on March 19, and only after the July news about the suspension of the deportations and favorable military developments did the number of such assertions considerably decrease. To secure the greatest possible publicity for its propaganda messages, the WRB utilized various channels, including American and neutral, especially Swiss, newspapers, but they got propaganda directly to Hungary through the mediation of American diplomats and the broadcasts of the Washington Office of War Information (OWI). The Board enlisted the cooperation of the British Broadcasting Corporation (BBC), Radio Algiers, and the Hungarian clandestine station Kossuth Radio, and it also sent messages to Hungary in the form of airdropped leaflets and of pamphlets via underground channels. Naturally, the most effective broadcasts addressed the population of Hungary in its native tongue, with the OWI beaming twenty Hungarian-language addresses into the country between March 24 and May 7. Most often, they included President Franklin D. Roosevelt's March 24 statement on the change of guard in Hungary and the British government's endorsement of the proclamation, statements by prominent American and HungarianAmerican personalities (e.g. senators, former New York governor Al Smith), clergymen (e.g. Protestant Géza Takaró, Roman Catholic Francis J. Spellman), and organizations (e.g. World Jewish Congress, Vaad Hahatzala Emergency Committee), as well as the resolutions of the American Senate and of the House Committee on Foreign Affairs. As for their content, WRB propaganda materials threatened the perpetrators with post-war trials while calling for the preservation of evidence against war criminals and for the support of the oppressed. They also advised against taking, by local Christians, confiscated Jewish property and, occasionally, brought attention to the activities of the French and Czech resistance, to the heroism of the inhabitants of the Warsaw ghetto, and to the bravery of citizens of foreign countries who performed outstanding acts to save Jews. Moreover, appeals by Americans of Hungarian descent stressed the Hungarian traditions of Christian-Jewish cooperative living and the importance of regaining the country's

\footnotetext{
${ }^{1}$ Although Hungary recalled its delegate from Washington a few days after the Japanese attack at Pearl Harbor, the United States issued an official declaration of war against that country only on July 17, 1942 (Tartakower and Grossmann 1944, 111).
} 
Halász, Dorottya. "Propaganda Versus Genocide: The United States War Refugee Board and the Hungarian Holocaust." AHEA: E-journal of the American Hungarian Educators Association, Volume 5 (2012): http://ahea.net/e-journal/volume-5-2012

honor and dignity. Finally, clergymen made Christian love and the Jewish roots of their religion the centerpiece of their argument (Foreign Relations of the United States 1966, 1015-16; Wyman 1984, 237, 257; Marks to Friedman and Weinstein, "Treasury Department, Inter Office Communication," May 15, 1944, WRB, Box 35, No. 4., FDRL).

The War Refugee Board was eager to enhance the effectiveness of its propaganda war by also ensuring the support of its major military allies. Whereas Great Britain was somewhat more willing than the Soviet Union to cooperate, the Board was unable to secure a personal message from Premier Joseph Stalin or any other high-ranking official of the USSR. Repeated attempts by the WRB to get Soviet cooperation reaped results only in the spring of 1945 when on April 23 Moscow issued a joint statement with London and Washington, threatening that any German guilty of maltreating detainees would be "ruthlessly pursued and brought to punishment" (Pehle, "Report of the War Refugee Board for the Week of January 15-20, 1945, WRB, Box 28, FDRL; O'Dwyer 1945, 56). But, for the most part, the Kremlin contributed to the psychological war campaign only indirectly, by permitting the operation of the communist-led Kossuth Radio in Soviet territory, whose appeals condemned the Nazi anti-Jewish actions, called for the organization of partisan units while urging Jews to join in, asked the Christian population and churches to support the persecuted, and broadcast reports on how the deportees were taken to and massacred in Poland (Lanyi to Weinstein, "Office of War Information, Washington, Memorandum," July 19, 1944, WRB, Box 35, No. 4, FDRL).

The aim of American propaganda was to influence ordinary Christians, Jews, as well as the authors and executors of anti-Jewish measures but was unsuccessful with all three groups. Appeals addressed to the Christian citizens pleading to conceal the Jews and assist in their illegal flight left the community at large unmoved. Although gentiles intervened in several instances to promote the survival of the victims, Raoul Wallenberg, the secret WRB agent in Budapest, reported on July 18 that this was "usually limited to helping friends by providing food and hiding places" (Wallenberg 1995, 236). Messages intended for the Jewish population accomplished even less. Based on previous experiences in German-controlled territories, on April 22 WRB Executive Director John Pehle asked the director of the Office of War Information to warn Hungarian Jews to seek refuge outside the big cities, to avoid wearing the yellow star, and to destroy community lists, but it was all a belated effort. One of the first decrees following the German occupation prohibited the possession of radios by Jews, making it unfeasible to warn the oppressed through the airwaves (Pehle to Davis, April 22, 1944, WRB, Box 35, No. 4, FDRL; Benoschofsky and Karsai 1958, 129-31). The isolation of Jews from all outside influences became complete with their ghettoization, which started in the provinces in mid-April and was followed by the first trial transports for Auschwitz-Birkenau leaving at the end of the month and with wholesale deportations starting on May 15. If propaganda messages had nevertheless reached the victims, it is still doubtful that great numbers of them would have acted contrary to the instruction of their trusted and respected Central Jewish Council leaders, which was to obey Nazi orders. As importantly, the majority of Hungarian Jews did not believe the news of the atrocities that had occurred in Poland and elsewhere, and even if they did, they believed that such horrors would not repeat themselves in Hungary. They confided in the Hungarian nation and, principally, in Regent Miklós Horthy so strongly that as late as April 1944 Chief Rabbi Ferenc Hevesi gave the following advice to his brethren: "Pray to God for yourself, your family, your children, but primarily and above all for your Hungarian Homeland! Love of Homeland, fulfillment of duty, and prayer should be your guiding light!" (Braham 1994, 1: 101). In the face of the misinformation spread by the Central Jewish Council, the only group who were working hard to facilitate the escape of Hungarian Jews into Romania and Yugoslavia were the Young Zionists, members of the Hechalutz youth, who during the weeks of ghettoization in the provinces attempted vainly to warn the victims against boarding the deportations trains (Cohen 1986, 75-79).

Many appeals in the WRB's psychological warfare campaign sought to change the actions of the perpetrators of anti-Jewish acts. If successful, this endeavor could have saved the Jewish community. The broadcasts cautioned that all who participated in the persecutions would face punishment after the war, but their impact was limited. Although, especially in the aftermath of the successful Allied military drive in 1944, the warnings might have affected the decision of a few involved persons to release Jews, for the perpetrators material gain from selling Jewish lives seems to have been more decisive than fear of punishment. In any case, fanatics like Eichmann remained completely indifferent to Allied threats, and the 
Halász, Dorottya. "Propaganda Versus Genocide: The United States War Refugee Board and the Hungarian Holocaust." AHEA: E-journal of the American Hungarian Educators Association, Volume 5 (2012): http://ahea.net/e-journal/volume-5-2012

prospect of a post-war trial also left the Fuhrer unaffected, who, sensing that he was losing the struggle for a grand German Empire, wanted to win at least his war against European Jewry.

The traditional psychological warfare utilized by the WRB to try to help the Jews was then ultimately a largely ineffectual response to the Hungarian crisis. It might have achieved better results if the Board had improved the quality of the broadcasts by, for example, addressing perpetrators personally by name. In April 1944 the WRB office in Washington had received ample information on the responsible individuals so that it could have turned its campaign against an anonymous mass into a predictably more effective campaign against "real" persons, such as the best-known and most notorious figures including Minister of the Interior Andor Jaross and Under Secretaries László Endre and László Baky, as well as other personalities in the government, legislation, military, army, youth movements, arts, and the press. Yet this crucial information of named responsible individuals was used only sporadically despite the fact that the WRB staff themselves were aware of the need for "finger-pointing broadcasts." London newspapers were also urging the publication of lists of persons who would face trial at war's end, arguing that "similar righteous sentiments" during the First World War remained unheeded, turning the present threats into hollow statements ("Project No. 13: Rescue of Refugees from Hungary," April 3, 1944, WRB, Box 4, FDRL; American Legation, Bern, to State, April 14, 1944, \#2320 and "A Concise Survey of the Situation of Hungarian Jews: No. 1," April 30, 1944, WRB, Box 58, FDRL; Marks to Friedman and Weinstein, June 2, 1944, WRB, Box 35, No. 4, FDRL; American Embassy, London, to State, July 17, 1944, \#5650, WRB, Box 35, No. 9, FDRL).

Shortly after his arrival in Budapest, Raoul Wallenberg criticized not only the content of the WRB broadcasts but also their style, advising that threats alone would not make the Allied propaganda efficient and that those who aided Jews deserved at least a promise of future help (Wallenberg 1995, 246-47). Since Hungary had become a German ally mostly in hope of recovering the territories that were lost in the Peace of Trianon at the end of the previous world war, Wallenberg's approach to influencing the actions of ordinary non-Jewish citizens could have been, in my view, applied on a higher level to influence the actions of Hungarian decision makers. The First and Second Vienna Awards of 1938 and 1940 had returned great chunks of formerly lost territories to Hungary, but in 1944 changes in the fortune of the Axis military jeopardized Hungarian spoils. Promises of post-war punishment for those involved in planning and executing anti-Jewish measures coupled with promises of favorable treatment of Hungary at the peace talks would therefore most probably have had an impact on leading members of the administration in Budapest.

The uneasiness of the American propaganda, largely the result of the tension between government and War Refugee Board objectives, was a further obstacle that decreased the effectiveness of the latter. The Roosevelt administration refused to support the WRB's endeavor to assert that because of the unique nature of the Nazi persecution of the Jews, the rescue of this group of people should receive priority among other refugee groups. Although it is plausible that by doing so the government simply wished to prevent a flare-up in domestic anti-Semitism, the fact remains that with the lack of Soviet and, especially, British backing, the United States was unwilling to take an open stand on behalf of Hitler's so-called archenemies, and it failed to question the wisdom of what had become the cornerstone of the Allied argument, that only Germany's military defeat could guarantee an end to the genocide. It is therefore no surprise that the executive order establishing the War Refugee Board made no explicit reference to the Jewish plight. It did state, however, that Board operations had to be "consistent with the successful prosecution of the war" (O'Dwyer 1945, n.p.).

A number of pieces among the propaganda materials of the WRB illustrate the tentativeness of the American rescue policy. The statement by President Roosevelt released at his press conference on March 24 on the Nazi extermination program and on condemning war criminals is one of the most telling examples. The original version drafted by the WRB placed heavy emphasis on anti-Jewish atrocities in Europe as well as on the possible consequences of the German takeover in Hungary, but by its final draft the declaration had become rather diluted. It first proclaimed the Allied military objectives and envisioned "a world in which tyranny and aggression can not exist; a world based upon freedom, equality and justice; a world in which all persons regardless of race, color or creed may live in peace, honor and dignity." It continued with enumerating Nazi and Japanese crimes against innocent civilians and American soldiers, which sections were then followed by an elaboration on the recent change of guard in Hungary and its most probably 
Halász, Dorottya. "Propaganda Versus Genocide: The United States War Refugee Board and the Hungarian Holocaust." AHEA: E-journal of the American Hungarian Educators Association, Volume 5 (2012): http://ahea.net/e-journal/volume-5-2012

negative effects on the Jews. Upon commenting on the Hungarian situation, the president contended that it "would be a major tragedy" if "these innocent people, who have already survived a decade of Hitler's fury, should perish on the very eve of triumph over the barbarism which their persecution symbolizes." To prevent such a scenario, FDR wanted to call attention once more to his government's determination that "none who participate in these acts of savagery shall go unpunished," and appealed to Germans and Europeans under German control to aid the victims and preserve the evidence against war criminals. Finally, the president also called upon the neutrals to admit all refugees who arrived at their borders, assuring them at the same time that the United States would find temporary havens for the fugitives and the means for their maintenance. Yet the conclusion of the message conveyed only vague allusions: "In so far as the necessity of military operations permit this Government will use all means at its command to aid the escape of all intended victims of the Nazi and Jap executioner-regardless of race or religion or color." This kind of ending indicates a step back in light of the resolve of the previous paragraphs as, on one hand, it fails to recognize the urge of Jewish rescue and, on the other, assistance to the refugees becomes a function of military necessities (Foreign Relations of the United States 1966, 1230-31; Wyman 1984, 256; O'Dwyer 1945, 49-51). The text of the presidential statement was consequently translated into several languages and disseminated in the form of airdropped leaflets, press releases, and radio broadcasts in Allied, neutral, and enemy territories. Since the publication of this declaration was the only occasion that the Chief Executive of the United States made a move independent of the Allied coalition on behalf of the persecuted European Jewry, including the Hungarians, it became a symbolic step marking the high point of American government concern. Later, FDR remained silent even in the middle of the international outcry over the fate of Hungarian Jews at the end of June when Pope Pius XII and King Gustav V of Sweden successfully demanded that the Budapest regime stop the death trains heading for Auschwitz-Birkenau.

In the fall of 1944 the War Refugee Board was tilting at windmills again in its attempts to obtain the release of forceful warnings aimed at Hungary. Having relaxed psychological warfare for over a month since the suspension of human transports from Hungary to Poland, reports of renewed or impending deportations made the Board's staff reevaluate its policy. In September John Pehle repeatedly urged the Office of War Information to beam broadcasts to Hungary, but Director Elmer Davis found it inadvisable to initiate a special campaign on behalf of the Jews now that the country had become a key battleground. Instead the OWI wished to turn all its resources against the "Hungarian determination to stick it out with the Nazis" as their "last satellite" (Pehle to Davis, September 5, 12, 1944, and Davis to Pehle, September 14, 1944, WRB, Box 35, No. 4, FDRL). Because of this unsuccessful demarche, the WRB this time chose to press the State Department into issuing warnings to the Third Reich and Hungary. A quasi-success, two messages on September 20 and October 6, little more than two weeks apart, resented the prospect of deportations and renewed the threat of post-war punishment. Yet the messages were unassertive in wording, and the second note to the Hungarian government on October 6 was even apologetic. After recalling the United States' determination to punish all who participated in anti-Jewish acts, it actually observed the possibility that the planned concentration of Jews in labor camps had evolved to achieve humanitarian ends and stated that, if that were the case, Washington would recognize the validity of such claims (Foreign Relations of the United States 1966, 1159-61, 1163-64).

In 1944 the last significant propaganda initiative of the WRB was the drive for a joint protest by the Allied military. By this time news of last-minute slaughter in forced labor and concentration camps as well as of the massacre of thousands of Hungarian labor servicemen and Budapest Jews had reached the West. Again the Board was unable to achieve complete success. Although, on November 7 General Dwight D. Eisenhower, the supreme commander of the Allied Expeditionary Force in Europe, issued a declaration prepared by the WRB, he was reluctant to make a specific reference to the Jewish inmates of concentration camps, and the original draft, which had made mention of Jews, had to be modified accordingly (Foreign Relations of the United States 1966, 1174-75; Braham 1994, 2: 970; Wallenberg 1995, 263; Wyman 1990, 16-19).

Clearly, a number of factors hampered the WRB's psychological warfare in Hungary, but there is one more element yet unveiled. The driving force behind the Board's campaign was the threat put forward by President Roosevelt himself that all anti-Jewish acts would meet severe punishment after the war. But there was no guarantee for such retribution as Pehle's office was informed rather belatedly, in August 1944, 
Halász, Dorottya. "Propaganda Versus Genocide: The United States War Refugee Board and the Hungarian Holocaust." AHEA: E-journal of the American Hungarian Educators Association, Volume 5 (2012): http://ahea.net/e-journal/volume-5-2012

due to the fact that no precedent under international law defined as war crimes acts committed by an enemy nation and its satellites against their own or each other's nationals, leaving the United Nations War Crimes Commission $^{2}$ without a plan for the punishment of persons guilty of atrocities against Axis and stateless Jews. To countermand this deficiency and to give more weight to American warnings, in the latter half of 1944, the WRB frequently asked the State Department for a declaration of government policy to make it clear that the United States indeed considered such crimes war crimes, but its efforts proved futile. Only as late as August 1945, after defeating the German-led coalition, did the victorious powers finally agree on hearing cases involving anti-Jewish acts among crimes against humanity (Wyman 1990, 24-31; Wyman 1984, 257-60).

Evaluating the role of American propaganda in influencing events in Hungary is no easy task. Obviously, the results are modest and difficult to trace. Most probably, the number of those saved by this means would not have been significantly higher even if the War Refugee Board could have forced its suggestions regarding the focus, style, and rhetoric of the campaign material. Moreover, it was naïve of the WRB to presume that this instrument of psychological warfare would produce substantial changes in the behavior of large numbers of people, whether ordinary Christians, Jews, or perpetrators and collaborators. At the same time, in early 1944 the United States and the WRB had apparently no other way to influence the outcome in Hungary. The only direct means to intervene would have been by bombing the deportation routes and the annihilation facilities at Auschwitz-Birkenau, but this is an area where the agency did not have the power to intervene, and it also lacked the support of the Roosevelt Administration as well as of the War Department whose opinions were indispensable in this matter. Sadly, the Allied policy that could see the genocide end only as a result of military victory ultimately triumphed over other options of humanitarian aid.

\section{Works Cited}

Adler, Cyrus, and Aaron M. Margalith. 1946. With Firmness in the Right: American Diplomatic Action Affecting Jews, 1840-1945. New York: American Jewish Committee.

Benoschofsky, Ilona, and Elek Karsai, eds. 1958. Vádirat a nácizmus ellen: Dokumentumok a magyarországi zsidóüldözés történetéhez. [The indictment of Nazism: Documents pertaining to the history of Hungarian Jewish persecutions]. Vol. 1. 1944. március 19-1944. május 15: A német megszállástól a deportálás megkezdéséig [March 19, 1944-May 15, 1944: From the German occupation to the beginning of the deportations]. Budapest: Magyar Izraeliták Országos Képviselete.

Braham, Randolph L. 1994. The Politics of Genocide: The Holocaust in Hungary. 2 vols. New York: Columbia UP.

2010. "Magyar, német és zsidó számítások és elszámítások a holokauszt utolsó szakaszában" [(False) expectations of Hungarians, Germans, and Jews during the last phase of the Holocaust]. Múlt és Jövő 2: 42-47.

Cohen, Asher. 1986. The Halutz Resistance in Hungary, 1942-1944. New York: Columbia UP. 1997. "Resistance and Rescue in Hungary." Genocide and Rescue: The Holocaust in Hungary, 1944. Ed. David Cesarani. Oxford: Berg. 123-34.

Druks, Herbert. 1977. The Failure to Rescue. New York: Robert Speller \& Sons.

Foreign Relations of the United States: Diplomatic Papers, 1944. Vol. 1. General. 1966. Washington, DC: US Government Printing Office.

Karsai, László. 2001. Holokauszt [Holocaust]. Budapest: Pannonica.

Leff, Laurel. 2005. Buried by The Times: The Holocaust and America's Most Important Newspaper. New York: Cambridge UP.

Mashberg, Michael. 1978. "Prejudice that Meant Death: The West and the Holocaust." Patterns of Prejudice 12.3: 19-32.

\footnotetext{
${ }^{2}$ The Commission operated between 1943 and 1948. Its first official meeting convened in January 1944. http://www.nationalarchives.gov.uk/records/research-guides/war-crimes-1939-1945.htm\#16202.
} 
The National Archives. http://www.nationalarchives.gov.uk/records/research-guides/war-crimes-19391945.htm\#16202. 3 Dec. 2011.

O’Dwyer, William. 1945. Final Summary Report of the Executive Director, War Refugee Board. Washington, DC: US Government Printing Office.

Records of the War Refugee Board. Franklin D. Roosevelt Library, Hyde Park, New York.

Tartakower, Arieh, and Kurt. R. Grossman. 1944. The Jewish Refugee. New York: Institute of Jewish Affairs of the American Jewish Congress and the World Jewish Congress.

Unity in Dispersion: A History of the World Jewish Congress. 1948. New York: World Jewish Congress. Wallenberg, Raoul. 1995. Letters and Dispatches, 1924-1944. Ed. Timothy Bent. New York: Arcade.

Wyman, David S. 1984. The Abandonment of the Jews: America and the Holocaust, 1941-1945. New York: Pantheon.

, ed. 1990. America and the Holocaust: A Thirteen-Volume Set Documenting the Editor's Book The Abandonment of the Jews. Vol. 9. War Refugee Board: Special Problems. New York: Garland. , ed. 1996. The World Reacts to the Holocaust. Baltimore: Johns Hopkins UP. 